\title{
Comparison of perceived genetic-genomic knowledge of nurse educators and graduate degree nursing students
}

\author{
Leighsa Sharoff * \\ School of Nursing, Hunter College, New York, NY, United States
}

Received: March 8, 2017

DOI: $10.5430 /$ jnep.v7n9p67

\author{
Accepted: March 28, 2017 \\ URL: https://doi.org/10.5430/jnep.v7n9p67
}

\begin{abstract}
Objective and rationale: Comparison of self-perceived genetic-genomic knowledge of nurse educators and graduate degree nursing students enrolled at a large diverse urban university in the US. Comfort level in performing genetic-genomic related tasks and its perceived relevance to nursing also explored. Practicing clinicians are expected to have Genetics and Genomics (G-G) knowledge to provide care to a client and their family with a genetic condition and faculty expected to be able to educate these practitioners.

Methods: Two groups of participants asked to complete identical survey instrument, Genetics/Genomics Literacy Assessment (GGLA). Data was collected from September 2014-December 2015. Deans/Directors from university's nursing programs ( $\mathrm{N}=$ 17) sent introductory email with survey link and asked to forward to their faculty. APRN/DNP students at one of the university's graduate programs sent email with survey link.

Results: Fifty-three nurse educators and thirty-six graduate degree nursing students completed survey. Comparison of categorical data revealed nurse educators perceived G-G knowledge correlated to graduate degree students. Majority of participants demonstrated significantly lower correct percentages $(<55 \%)$ correct] to survey questions. Majority of participants $(>75 \%)$ attitude agree it is important for nurses to know this content and be able to teach this material. However, majority $(>75 \%)$ were not comfortable with teaching or explaining this material.

Conclusions: Nurse educators need to be knowledgeable in order to educate their students who are expected to practice at advanced efficiency. A prepared nursing workforce is crucial for the translation of G-G integration into personalized precision healthcare.
\end{abstract}

Key Words: Genetics-genomics, Genetic-genomic knowledge, Genetic-genomic education, Clinical comfort, Nurse educators, Graduate degree nursing students

\section{INTRODUCTION}

With the completion of the international Human Genome Project in 2003, the sequencing of the human DNA genetic code was accomplished in 2007. ${ }^{[1]}$ This collaborative event led to significant changes in healthcare, leading the way for a multifaceted approach to delivering care that defines the personalized precision of one's individual DNA, culminating with the genomic era. Genomics is the study of the structure and function of the genome and its interactions with the environment while genetics is the study of inheritance and variation. ${ }^{[2]}$ Simply, genomics, which includes genetics, is the study of how genetic variation impacts health. ${ }^{[3]}$ With

*Correspondence: Leighsa Sharoff; Email: 1sharoff@hunter.cuny.edu; Address: School of Nursing, Hunter College, New York, NY, United States. 
genomic knowledge now a standard required competency, all healthcare providers are mandated to be well-informed of this content. To that end, nurse educators must maintain a minimum knowledge base in order to further the educational foundation for students. However, a gap still exists demonstrating a lack of an appropriate foundational knowledge base leading to an inability to effectively integrate this content into practice. ${ }^{[4,5]}$ Understanding genetics-genomics (G-G) is increasingly relevant in clinical practice, and faculty is expected to be able to educate the next generation of practitioners. Practicing clinicians are expected to have this basic knowledge to adequately and effectively participate in the care of a client and family with a genetic condition.

\subsection{Purpose}

This study explored the descriptive comparison of selfperceived genetic-genomic (G-G) knowledge of nurse educators and graduate nursing students from a large diverse urban university in the United States. Comfort level in performing genetic-genomic related tasks in practice and its perceived relevance to the nursing role was also explored.

\subsection{Literature review}

The impact of nursing education science to embrace genomicgenomic content integration must occur if nursing is to remain a collaborative member of the inter-professional healthcare team. The National Coalition for Health Professional Education in Genetics (NCHPEG) developed the Core Competencies in Genetics for Health Professionals, to encourage clinicians and other professionals to integrate geneticsgenomics knowledge, skills, and attitudes into routine health care, thereby providing effective and comprehensive services to individuals and families. ${ }^{[6]}$ These core competencies describe the necessary minimum knowledge and skills for the educational preparedness of practicing nurses and nursing students. ${ }^{[6]}$ Providing essential educational information, support and guidance pertaining to genetics-genomics is expected for all levels, from initial pre-licensure preparation to graduate degree practicing nurse professionals. ${ }^{[7]}$ The influence on practice is swiftly advancing and with emerging ethical, legal and social issues, including confidentiality, therapeutic decision-making capacity, informed consent, genetic screening and testing, risk assessment, prevention, diagnosis, prognosis and research are necessary to guarantee the delivery of appropriate and unprejudiced health care for all. ${ }^{[8,9]}$ The clinical significance requires a broad familiarity of genetic-genomic concepts, staying informed of new genomic technology and being able to incorporate this information through informed comprehensive nursing practice. ${ }^{[2]}$

Expanding on the core proficiencies, prominent national and 68 international nursing organizations established guidelines for the integration of contemporary G-G knowledge related to nursing, instituting a foundational knowledge base as a basic requirement in nursing education. ${ }^{[6,10-13]}$ As seen in Table 1, these supplementary documents delineate central genetic-genomic competencies explicitly for all registered nurses, including pre-licensure baccalaureate through advanced graduate levels. ${ }^{[2]}$ As patients and their families become more aware of the genetic impact to health and disease, nurses in all areas of practice are being asked to address basic genetics-genomics-related questions and service needs. ${ }^{[14]}$ Nurse professionals need to be appropriately educated in order to effectively integrate these competencies into practice, continuing the path of advocators, providers of patient education and referrals.

\subsubsection{Nurse educators and genetic-genomic knowledge}

The increasing importance of G-G literacy in nursing requires those in practice meet the needs of patients and families facing genetic conditions and disorders. However, there is an inadequacy of practicing nurses to meet these geneticgenomic concerns. ${ }^{[15]}$ There is an inability to augment genetic-genomic content within nursing education, given the 'large gap' between what nurses actually know and what they need to know in this genetic-genomic era ${ }^{[4]}$ coupled with nurse educators not sufficiently trained to "close the gap'. ${ }^{[16]}$ Many nursing faculty are unprepared to teach genetic-genomic content, demonstrating a 'paucity' of genetic knowledge. ${ }^{[17,18]}$ Lack of knowledge of G-G and a lack of confidence in the nurse educators' ability to teach this complex content are significant obstacles to integrating this specialty. Numerous studies on nurse educators' preparedness to fully implement genetic-genomic content into nursing curricula has demonstrated the continued need to further faculty education. ${ }^{[5,19-22]}$ Nursing faculty must be made aware of this deficiency and be prepared to enhance their own knowledge and that of their students' during this revolutionized genomic era. Although there is no universal measure of genetic-genomic literacy for nurses at any educational level or clinical practice ${ }^{[23]}$ it is still necessary and important to fully explore the integration of G-G into nursing curricula. Targeted genetic-genomic education is a requisite to guarantee optimal advanced graduate degree nurse practitioners preparation to meet the competency of integrating the standards and scope of G-G into personalized precision medicine. ${ }^{[20]}$ One early study specifically on faculty members' perception of medical genetics and it integration into nurse practitioner (NP) curricula showed that most faculty did not feel comfortable teaching genetics and did not have formal training but perceived genetics as important content for NP education inclusion. ${ }^{[24]}$ The complexity of this com-

ISSN 1925-4040 E-ISSN 1925-4059 
petency requires nurse educators to enhance their own G-G ricula to ensure the continued advancement of the profession knowledge base and effectively incorporate into nursing cur- as a collaborative informed partner in health care.

Table 1. Genetic-genomic nursing documents

\begin{tabular}{|c|c|c|}
\hline American Nurses Association & Personalized Medicine & http://www.nursingworld.org/genetics \\
\hline $\begin{array}{l}\text { Genetics/Genomics Nursing: Scope \& } \\
\text { Standards of Practice }\end{array}$ & $\begin{array}{l}\text { ANA/ISONG Standards of } \\
\text { Genetics/Genomics Nursing } \\
\text { Practice, } 2007\end{array}$ & $\begin{array}{l}\text { http://www.nursingworld.org/MainMenuCategories/ } \\
\text { EthicsStandards/Resources/Genetics-1/Genetics-and } \\
\text {-Genomics-Nursing-Scope-and-Standards.pdf }\end{array}$ \\
\hline $\begin{array}{l}\text { Core Competencies in Genetics for } \\
\text { Health Professionals }\end{array}$ & $\begin{array}{l}\text { National Coalition for Health } \\
\text { Professional Education in } \\
\text { Genetics [The Jackson } \\
\text { Laboratory] }\end{array}$ & $\begin{array}{l}\text { https://www.jax.org/education-and-learning/clinical } \\
\text {-and-continuing-education/ccep-non-cancer-resourc } \\
\text { es/core-competencies-for-health-care-professionals }\end{array}$ \\
\hline $\begin{array}{l}\text { Essentials of Genetic and Genomic } \\
\text { Nursing: Competences, Curricula } \\
\text { Guidelines, and Outcome Indicators }\end{array}$ & $\begin{array}{l}\text { Consensus Panel on } \\
\text { Genetic/Genomic Nursing } \\
\text { Competencies, } 2009\end{array}$ & $\begin{array}{l}\text { http://www.nursingworld.org/MainMenuCategories/ } \\
\text { EthicsStandards/Resources/Genetics-1/EssentialNur } \\
\text { singCompetenciesandCurriculaGuidelinesforGeneti } \\
\text { csandGenomics.pdf }\end{array}$ \\
\hline $\begin{array}{l}\text { Essentials of Baccalaureate Education } \\
\text { for Professional Nursing Practice }\end{array}$ & $\begin{array}{l}\text { American Association of Colleges } \\
\text { of Nursing, } 2008\end{array}$ & $\begin{array}{l}\text { http://www.aacn.nche.edu/education-resources/Bacc } \\
\text { Essentials08.pdf }\end{array}$ \\
\hline $\begin{array}{l}\text { Essential Genetic and Genomic } \\
\text { Competencies for Nurses With } \\
\text { Graduate Degrees }\end{array}$ & $\begin{array}{l}\text { Consensus Panel on } \\
\text { Genetic/Genomic Nursing \& the } \\
\text { American Nurses Association, } \\
2011\end{array}$ & $\begin{array}{l}\text { http://www.nursingworld.org/MainMenuCategories/ } \\
\text { EthicsStandards/Resources/Genetics-1/Essential-Ge } \\
\text { netic-and-Genomic-Competencies-for-Nurses-With- } \\
\text { Graduate-Degrees.pdf }\end{array}$ \\
\hline $\begin{array}{l}\text { Bringing Science to Life: NINR } \\
\text { Strategic Plan }\end{array}$ & $\begin{array}{l}\text { National Institute for Nursing } \\
\text { Research (NINR) }\end{array}$ & $\begin{array}{l}\text { https://www.ninr.nih.gov/sites/www.ninr.nih.gov/fil } \\
\text { es/ninr-strategic-plan-2011.pdf }\end{array}$ \\
\hline $\begin{array}{l}\text { Genetics/Genomics in Nursing and } \\
\text { Midwifery }\end{array}$ & $\begin{array}{l}\text { Genetics in Nursing \& Midwifery } \\
\text { Task and Finish Group, } 2011\end{array}$ & $\begin{array}{l}\text { https://www.gov.uk/government/uploads/system/upl } \\
\text { oads/attachment_data/file/215250/dh_131947.pdf }\end{array}$ \\
\hline $\begin{array}{l}\text { Fit for Practice in the Genetics Era A } \\
\text { competence based education } \\
\text { framework for nurses, midwives and } \\
\text { health visitors }\end{array}$ & $\begin{array}{l}\text { Genomics Policy Unit, University } \\
\text { of Glamorgan, and the Medical } \\
\text { Genetics Service for Wales, } \\
\text { University Hospital of Wales, } \\
2003\end{array}$ & $\begin{array}{l}\text { http://genomics.research.southwales.ac.uk/media/fil } \\
\text { es/documents/2012-05-24/Extended_summary__co } \\
\text { mpetence_framework_2003.pdf }\end{array}$ \\
\hline
\end{tabular}

\subsubsection{Practicing nurses' and genetic-genomic knowledge}

Graduate degree/advanced practice registered nursing professionals' (APRNs, including nurse practitioners [NP], nurse midwives and Doctor of Nursing [DNP]) role is of clinical competency to improve outcomes, apply and generate new knowledge through research and co-participants in advancing the science and use of genetic-genomic knowledge to further care for their patients and families in all areas in clinical practice. ${ }^{[25,26]}$ However, APRNs who have limited educational training of G-G lack the knowledge competency to apply clinically significant findings. ${ }^{[27]}$ APRNs who "lack the knowledge to understand the application... within the complex area of patient care risk missing opportunities to use genomic discoveries, optimize patients' health care, promote patient understanding, and facilitate patient/provider engagement". ${ }^{[27]}$ Despite the growing use of G-G significance in clinical practice, health professional knowledge about genomic information and confidence in using it have not kept pace, as many health care providers do not have either the knowledge or the tools they need in order to apply genetic-genomic information in their day-to-day practices. ${ }^{[28]}$ APRNs and DNPs maybe unprepared to fully integrate genetic-genomic concepts to maximize health outcomes for patients and families based on nurse educators preparedness to implement genetic-genomic competencies into nursing curricula. An educational preparedness disparity continues with G-G content to APRN students. ${ }^{[22]}$ There is a substantial competency deficit in the nursing workforce ${ }^{[20]}$ and basic genetic-genomic proficiency is relevant for APRNs given their roles encompasses mentoring other nurses and patient education. ${ }^{[22]}$ In order to continue to improve patient outcomes, all nurses, at all educational levels, need to address the genetic-genomic knowledge deficits in the practicing workforce. Numerous studies have demonstrated that graduate degree nursing professionals perceive they have minimum knowledge of genetics-genomics. ${ }^{[22,29-32]}$ A study exploring the comparison of data from 2005 and 2010 of nursing faculty and APRNs G-G knowledge and self-perceived 
comfort levels demonstrated that inconsistencies still exist in this content. ${ }^{[22]}$ It is necessary for the nursing profession and nurse educators, specifically, to enhance their overall preliminary knowledge, skills and attitude about G-G to prepare for the transformation in healthcare that is already underway. A well-prepared nursing faculty is needed to adequately prepare the future generation of professional nurses. The incorporation of the requisite knowledge, skills and abilities continue to fluctuate in the nursing profession ${ }^{[33]}$ and maintaining educational competency to meet this need is incumbent of nurse educators to adequately teach this content. The number of nurses whose education has prepared them to take over advanced practice roles is currently not sufficient and this deficiency is expected to continue through the next decade. ${ }^{[34]}$ The educational process varies depending on the country or region. For example, for most countries in the World Health Organization/European Region, 12 years of education is required before entry into an educational programme in nursing and midwifery, ${ }^{[34]}$ yet G-G concept is still lacking in the curricula.

\section{DESign, RECRUITMENT AND DATA COL- LECTION}

A descriptive comparison of nurse educators (NE) to graduate students (APRNs and DNP) self-perceived genetic-genomic knowledge and comfort level was assessed. Institutional review board (IRB) approval was obtained prior to the beginning of data collection, occurring September 2014-December 2015. Deans and Directors from the university's nursing programs $(\mathrm{N}=17)$ were sent an introductory email by a research assistant (RA) with a link to the survey and asked to forward the email to their nursing faculty, with an email reminder every 2 months. APRN/DNP students at one of the university's graduate nursing programs were sent an introductory email by a RA with a link to the survey, with a reminder email every 2 months.

Participants who clicked the survey link were asked to read the consent form, indicate their willingness to participate and not record or share the items by checking a box that led to the survey. The online anonymous responses were collected using Survey Monkey and imported into an SPSS database for analysis. Survey permission was received by the original creator, ${ }^{[18]}$ with the researcher adapting the survey to meet the needs of this study, with additional survey questions to explore comfort and confidence level related to genetic-genomic integration into practice. The modified survey, the Genetic-Genomic Literacy Assessment (GGLA) received IRB approval. No time limit was imposed and participants were unable to retake the survey once the link was clicked. There was no identifiable data obtained from any participant. Participation was voluntary and confidentiality was assured.

\subsection{Participants}

Fifty-three nurse educators [ $89 \%$ female $(\mathrm{N}=48)$ and $10 \%$ male $(\mathrm{N}=5)$ ] completed the online survey.

Majority of nurse educators (NE) were between the ages of 51-60 (mean age $=48.7)$. Twenty NE $(37 \%)$ had the majority of 1-10 years in nursing (mean $=13.65)$. Highest degree obtained was a doctorate for 24 participants (48.98\%) and 22 were graduate level (masters) prepared (44.90\%). Majority did not have genetics-genomics content in their pre-licensure undergraduate education ( $\mathrm{N}=42,77.08 \%), 46$ participants $(89.58 \%)$ were interested in enhancing their G-G knowledge and the majority were interested in learning how to integrate this content into their current program $(\mathrm{N}=41,75.51 \%)$. The American Association of College of Nursing (AACN) data reported that the mean age of master's and doctorally prepared United States nurse educators is greater than 51 years, consequently the majority received their original college edification prior to the beginning of the Human Genome Project. ${ }^{[35]}$ In the European Region alone, there are an estimated 7.3 million nurses and midwives, which are still not considered adequate to meet current and projected future needs of patient care, especially those with genetic conditions $^{[34]}$ (see Table 2).

Graduate students (APRNs, $\mathrm{N}=31$ ) were primarily female $(\mathrm{N}=26,80.65 \%)$ with the average age between $31-40(\mathrm{~N}=$ $18,54.84 \%$, mean age $=39.5)$. All but one participant graduated from their pre-licensure undergraduate nursing program from 2001 onward $(\mathrm{N}=30,96.78 \%)$ and 26 participants did not have genetic-genomic content in their pre-licensure program $(80.65 \%)$. Five DNP students also participated, with three females (60\%) and two males. Again, all but one participant $(\mathrm{N}=4)$ did not have genetic-genomic content in their pre-licensure program. Statistically there are over 267,000 APRNs in the U.S. ${ }^{[36,37]}$ The number of students enrolled in DNP programs is over 21,995 as of 2015 in the 289 DNP in programs across the United States. ${ }^{[38]}$ Consequently, the percent of these students receiving genetic-genomic educational content is minimal. Prior education and training in genetics for both educator and graduate degree student is still inadequate $^{[22]}$ (see Table 3).

\subsection{Instrument/assessment of self-perceived genetic- genomic knowledge and comfort level}

A systematic literature review to identify instruments to explore self-perceived genetic knowledge was conducted and the validated survey is a 15-item multiple choice, used to assess genetic-genomic knowledge. ${ }^{[18]}$ The 15 ques-

ISSN 1925-4040 E-ISSN 1925-4059 
tions ranged from interpreting reciprocal translocation in the genome; terminology such as phenotypic polymorphism and allele; understanding Mendelian inheritance diseases; genetic testing concepts; understanding fertility implications of a reciprocal translocation; standardized symbols utilized in a patient's pedigree; implications regarding penetrance; understanding inheritance via pedigree and legal protection from discrimination concerning one's genotype. The survey was reviewed for clarity, accuracy and comprehensiveness from 3 professors knowledgeable in genetics and 4 members of the International Society of Nurses in Genetics (ISONG) and was piloted with findings that it was not arduous or unreasonable to complete. ${ }^{[18]}$ Even though this survey was initially utilized for baccalaureate nurse educators in the United States, it is an appropriate survey to establish self-perceived genetic knowledge regarding the essential concepts of G-G and the nurses' understanding of this complex content. Modification to the original survey included 7 questions related to perceptions and attitudes about genetics integration into nursing curricula and 5 questions related to comfort level in practice/education. The adapted survey, Genetics/Genomics Literacy Assessment (GGLA), also included basic demographic data. Clinical comfort with this complex erudition correlates to confidence if graduate degree nursing professionals are to be co-participants with their patients and families in the healing-caring process. Nurses' overall confidence and comfort in performing genetic-genomic related tasks is relatively low. ${ }^{[39]}$ Understanding educational training confirms the need for more inclusion of genetic-genomic content into curriculum and the need to further educate nurse faculty.

Table 2. Characteristics of nurse educators

\begin{tabular}{|c|c|c|c|}
\hline & NE $(\mathrm{N}=53)^{*}$ & Mean & SD \\
\hline \multicolumn{4}{|l|}{ Gender } \\
\hline Female & $48(89.36 \%)$ & 1.89 & .31 \\
\hline Male & $5(10.64 \%)$ & & \\
\hline Age & MEAN: 48.7 years & & \\
\hline $25-30$ & $4(8.51 \%)$ & & \\
\hline $31-40$ & $2(4.26 \%)$ & & \\
\hline $41-50$ & $11(21.28 \%)$ & 3.70 & 1.17 \\
\hline $51-60$ & $24(42.55 \%)$ & & \\
\hline $61-70$ & $11(21.28 \%)$ & & \\
\hline $71-75$ & $1(2.13 \%)$ & & \\
\hline \multicolumn{4}{|l|}{ Total Years in Nursing } \\
\hline $1-10$ & $20(37 \%)$ & & \\
\hline $11-20$ & $17(32 \%)$ & 13.65 & \\
\hline $21-30$ & $8(4.24 \%)$ & & \\
\hline $31-40$ & $8(4.24 \%)$ & & \\
\hline \multicolumn{4}{|l|}{ Primary Clinical Area } \\
\hline Community/Public Health & $4(8.51 \%)$ & & \\
\hline Psychiatric/Mental Health & $9(19.15 \%)$ & & \\
\hline Maternity/Newborn & $6(12.77 \%)$ & & \\
\hline Medical/Surgical & $16(34.04 \%)$ & 3.77 & 1.70 \\
\hline Pediatrics & $4(8.51 \%)$ & & \\
\hline Geriatrics & $3(6.38 \%)$ & & \\
\hline Other & $5(10.64 \%)$ & & \\
\hline \multicolumn{4}{|l|}{ Highest Degree Obtained } \\
\hline BSN & $3(6.12 \%)$ & & \\
\hline MSN & $22(44.90 \%)$ & 2.43 & .61 \\
\hline Doctorate & $24(48.98 \%)$ & & \\
\hline \multicolumn{4}{|l|}{ Genetics-Genomics in BSN } \\
\hline Yes & $11(22.92 \%)$ & 1.77 & .42 \\
\hline No & $42(77.08 \%)$ & & \\
\hline \multicolumn{4}{|c|}{ Interest in Enhancing Knowledge } \\
\hline Yes & $46(89.58 \%)$ & 1.10 & .31 \\
\hline No & $5(10.42 \%)$ & & \\
\hline \multicolumn{4}{|c|}{ Interest in Learning about Integration } \\
\hline Yes & $41(75.51 \%)$ & 1.24 & .43 \\
\hline No & $12(24.49 \%)$ & & \\
\hline
\end{tabular}

*some questions may not tally to 100 due to no response 
Table 3. Characteristics of graduate students

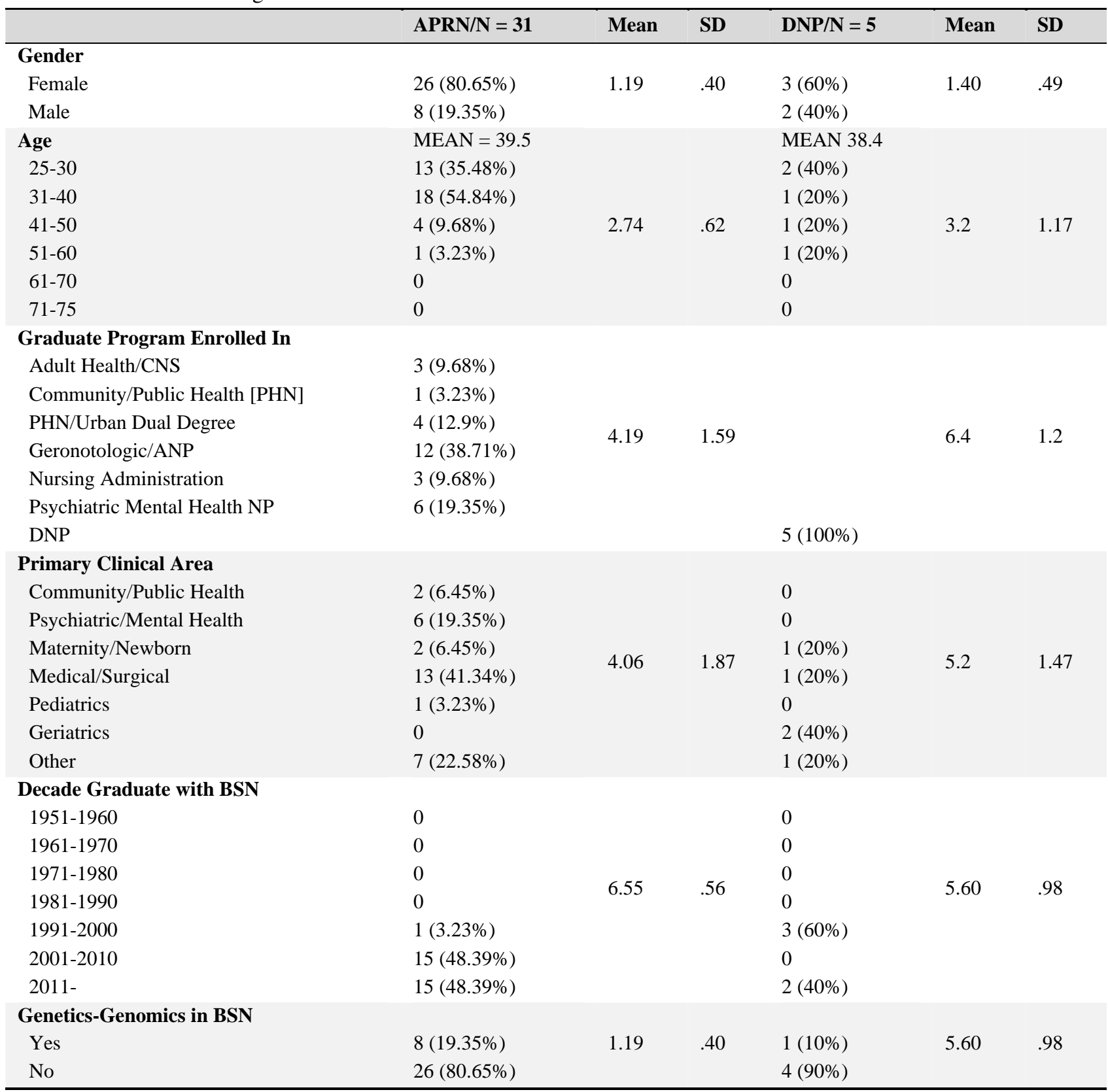

\subsection{Statistical analysis}

Data were coded and entered into an SPSS database. Results were analyzed using descriptive statistical techniques to summarize categorical data. Data distribution was performed using frequency distribution of both participant correct responses and percentages of those responses. Statistician consultation regarding the categorical comparison of the GGLA was obtained.

\section{Results}

Comparison of the categorical data revealed nurse educators perceived G-G knowledge correlated to graduate degree nursing students. Fifty-three NE and thirty-six graduate degree nursing students (APRNs [N = 31] and DNP [N = 5]) completed the survey. Of the 15 questions, majority of all participants for 8 survey questions demonstrated significantly lower correct percentages $(<55 \%$ correct). These included limited knowledge related to reciprocal translocation in the genome; understanding Mendelian inheritance diseases; genetic testing concepts; understanding amniocentesis results with phenotypic abnormality; standardized symbols utilized in a patient's pedigree and understanding inheritance via pedigree (see Table 4). 
Table 4. GGLA item scores for nurse educator and graduate student participants

\begin{tabular}{lllllll}
\hline & NE (N $\mathbf{5 3})$ & Mean/SD & APRN (N = 31) & Mean/SD & DNP (N = 5) & Mean/SD \\
\hline Item 1: Allele & $26^{*}\left(49 \%{ }^{* *}\right)$ & $1.96 / 0.95$ & $17^{*}\left(54.84 \%{ }^{* *}\right)$ & $1.94 / 0.91$ & $2 *(40 \% * *)$ & $2.00 / 1.10$ \\
Item 2: Phenotypic polymorphisms & $27(51 \%)$ & $2.00 / 1.24$ & $23(74.19 \%)$ & $1.52 / 1.01$ & $5(100 \%)$ & $1.00 / 0.00$ \\
Item 3: Reciprocal translocation & $8(16 \%)$ & $2.74 / 1.34$ & $4(12.9 \%)$ & $3.29 / 1.17$ & $5(100 \%)$ & $4.00 / 0.00$ \\
Item 4: Autosomal recessive & $23(45.1 \%)$ & $3.06 / 1.07$ & $8(26.6 \%)$ & $2.67 / 1.04$ & $2(40 \%)$ & $2.20 / 1.47$ \\
Item 5: Somatic cell mutation & $28(54.9 \%)$ & $2.39 / 0.89$ & $22(70.97 \%)$ & $2.74 / 0.84$ & $1(20 \%)$ & $1.60 / 0.80$ \\
Item 6: Genetic testing & $9(17.65 \%)$ & $2.06 / 1.16$ & $4(12.9 \%)$ & $2.35 / 1.23$ & $0(0 \%)$ & $2.40 / 0.80$ \\
Item 7: X-linked recessive & $25(51.02 \%)$ & $1.92 / 1.08$ & $17(54.84 \%)$ & $2.10 / 1.30$ & $1(20 \%)$ & $3.40 / 1.20$ \\
Item 8: BRCA1 allele & $41(82 \%)$ & $3.70 / 0.67$ & $29(93.55 \%)$ & $3.90 / 0.39$ & $4(80 \%)$ & $3.80 / 0.40$ \\
Item 9: Carrier testing & $44(88 \%)$ & $2.92 / 0.34$ & $28(93.55 \%)$ & $2.90 / 0.40$ & $5(100 \%)$ & $3.00 / 0.00$ \\
Item 10: GINA/Health Insurance & $43(87.76 \%)$ & $3.06 / 0.42$ & $28(93.55 \%)$ & $3.07 / .025$ & $5(100 \%)$ & $3.00 / 0.00$ \\
Item 11: Pregnancy DNA mutations & $19(38 \%)$ & $2.34 / 1.12$ & $10(34.48 \%)$ & $2.41 / 1.10$ & $4(80 \%)$ & $1.40 / 0.80$ \\
Item 12: Patient history & $43(86 \%)$ & $2.12 / 0.43$ & $29(93.55 \%)$ & $2.06 / 0.25$ & $4(80 \%)$ & $2.20 / 0.40$ \\
Item 13: Pedigree symbol & $18(38.3 \%)$ & $2.51 / 1.03$ & $24(80 \%)$ & $2.70 / .064$ & $2(40 \%)$ & $2.80 / 0.75$ \\
Item 14: Penetrance & $34(70.83 \%)$ & $3.63 / 0.67$ & $15(48.39 \%)$ & $3.26 / 0.88$ & $4(80 \%)$ & $3.60 / 0.80$ \\
Item 15: Interpreting pedigree & $10(20.83 \%)$ & $2.52 / 1.04$ & $4(12.9 \%)$ & $2.35 / 0.86$ & $2(40 \%)$ & $2.00 / 0.89$ \\
\hline
\end{tabular}

Note. Item scores $=$ number of participant correct responses* and percentage correct**

The majority (> 75\%) of participants' attitude agreed it is important for nurses to know this content; be able to teach this material and it is the role of the nurse educator to prepare students. However, majority ( $>75 \%$ ) were not comfortable with teaching or explaining this material to students and/or patients. Unfamiliarity and inexperience with G-G content and concepts and a lack of confidence in ones' ability to discuss this topic are obviously major barriers to being able to full integrate this content into ones' practice (see Tables 5 and 6).

Table 5. Comfort level of genetics-genomics

\begin{tabular}{|c|c|c|c|c|c|c|c|c|}
\hline Items & $1 * *$ & $2 * *$ & $3 * *$ & $4 * *$ & $5 * *$ & Median & Mean & SD \\
\hline \multirow{3}{*}{$\begin{array}{l}\text { 1. How comfortable are you in collecting a } \\
\text { patient's family history, drawing a 3-generation } \\
\text { pedigree and analyzing that pedigree? }\end{array}$} & $: 5$ & E: 3 & $: 17$ & E: 24 & E: 1 & E: 3.5 & E: 3.26 & NE: 0.98 \\
\hline & $\mathrm{N}: 1$ & J: 2 & & $: 20$ & & T: 4.0 & 3.58 & N: .079 \\
\hline & & NP: 1 & NP: 4 & JP: 0 & & NP: 3.0 & NP: 2.80 & DNP: 0.40 \\
\hline \multirow{3}{*}{$\begin{array}{l}\text { 2. How comfortable are you in sharing your } \\
\text { knowledge of genetics/genomics in the clinical } \\
\text { setting? }\end{array}$} & JE: 1 & & $: 11$ & 31 & & NE: 4.0 & NE: 3.50 & NE: 0.81 \\
\hline & RN: 0 & RN: 2 & RN: 8 & RN: 21 & & RN: 4.0 & RN: 3.61 & RN: 0.61 \\
\hline & NP: 0 & DNP: 2 & DNP: 2 & DNP: 1 & DNP: 0 & DNP: 3.0 & DNP: 2.80 & DNP: 0.75 \\
\hline \multirow{3}{*}{$\begin{array}{l}\text { 3. How comfortable are you in requesting more } \\
\text { education about genetic diseases and genetic } \\
\text { counseling? }\end{array}$} & NE: 7 & NE: 19 & NE: 13 & NE: 8 & NE: 2 & NE: 2.0 & NE: 2.57 & NE: 1.05 \\
\hline & $\mathrm{N}: 2$ & $\mathrm{~N}: 8$ & $\mathrm{~N}: 10$ & RN: 11 & $\mathrm{~N}: 0$ & RN: 3.0 & RN: 2.93 & RN: 0.93 \\
\hline & & & DNP: 1 & DNP: 1 & DNP: 0 & DNP: 2.5 & DNP. 275 & DNP: 0.83 \\
\hline \multirow{3}{*}{$\begin{array}{l}\text { 4. How comfortable are you in explaining the } \\
\text { Mendelian inheritance patterns to patients } \\
\text { (autosomal dominant; autosomal recessive; } \\
\text { X-linked disorders; Mitochondrial)? }\end{array}$} & NE: 3 & NE: 4 & NE: 18 & NE: 25 & & NE: 3.5 & NE: 3.30 & NE: 0.85 \\
\hline & RN: 1 & RN: 4 & & RN: 22 & & $\mathrm{RN}: 4.0$ & RN: 3.52 & RN: 0.84 \\
\hline & DNP: 0 & DNP: 1 & DNP: 3 & DNP: 1 & DNP: 0 & DNP: 3.0 & DNP: 3.00 & DNP: 0.63 \\
\hline \multirow{3}{*}{$\begin{array}{l}\text { 5. How comfortable are you in teaching the } \\
\text { concepts of genetics/genomics to fellow nurses? }\end{array}$} & NE: 0 & & 11 & : 33 & IVE. 1 & NE: 4.0 & NE: 3.60 & NE: 0.69 \\
\hline & & & & RN: 21 & & $\mathrm{RN}: 4.0$ & $\mathrm{RN}: 3.52$ & $\mathrm{RN}: 0.82$ \\
\hline & DNP: 0 & DNP: 1 & DNP: 4 & DNP: 2 & DNP: 0 & DNP: 3.0 & DNP: 3.20 & DNP: 0.75 \\
\hline
\end{tabular}

Note. Nurse Educator (NE; $\mathrm{N}=53)^{*}$; APRN (RN; $\left.\mathrm{N}=31\right) *$ DNP $(\mathrm{N}=5) * ;$ *Tally may not equal total of participants due to no answer reported; **Legend: $1=$ Extremely Comfortable; 2 = Very Comfortable; 3 = Somewhat Comfortable; 4 = Not; Comfortable; 5 = Unsure of Comfort Level.

\section{Discussion}

The majority of NE (77\%) received their pre-licensure nursing education without genetic-genomic content, which correlates to the majority of graduate students also not receiving genetic-genomic content in their pre-licensure training $(80 \%$
APRN; 90\% DNP). Thus, it is understandable as to why faculty self-perceived knowledge of genetics-genomics content is similar to that of their students. ${ }^{[5]}$ Fortunately, with the current requirement of this core competency, pre-licensure nursing curricula are now integrating this content into their 
programs, leading to future nurses having the knowledge and confidence for evidence-based clinical application of genetic-genomics. ${ }^{[7,11,33,40]}$ It is required of nursing faculty to prepare students for the emerging genetic-genomic content and its application to practice. This "preparation extends far beyond the science and technology", addressing "the issues that promote patient adaptation to, as well as personal and clinical decisions" and their possible consequences, and the "interpretation and impact of information, risk perception, and available resources". ${ }^{[41]}$

Table 6. Perceptions and attitudes about genetics-genomics integration into nursing curriculum

\begin{tabular}{|c|c|c|c|c|c|c|c|}
\hline Items & $\begin{array}{l}\text { Strongly } \\
\text { Agree }\end{array}$ & Agree & $\begin{array}{l}\text { Disagr } \\
\text { ee }\end{array}$ & $\begin{array}{l}\text { Strongly } \\
\text { Disagree }\end{array}$ & Median & Mean & SD \\
\hline \multirow{3}{*}{ 1. Genetics/genomics important for a nurse to know } & NE: 20 & NE: 21 & NE: 2 & NE: 1 & NE: 2.00 & NE: 1.68 & NE: 0.65 \\
\hline & RN: 10 & RN: 21 & $\mathrm{RN}: 0$ & $\mathrm{RN}: 0$ & $\mathrm{RN}: 2.00$ & $\mathrm{RN}: 1.68$ & RN: 0.47 \\
\hline & DNP: 3 & DNP: 2 & DNP: 0 & DNP: 0 & DNP: 1.0 & DNP: 1.40 & DNP: 0.49 \\
\hline \multirow{3}{*}{$\begin{array}{l}\text { 2. Preparing nurses to use genetics/genomics is an } \\
\text { important role of nurse educators }\end{array}$} & NE: 17 & NE: 24 & NE: 6 & NE: 1 & NE: 2.00 & NE: 1.90 & NE: 0.91 \\
\hline & RN: 10 & RN: 20 & $\mathrm{RN}: 1$ & $\mathrm{RN}: 0$ & $\mathrm{RN}: 2.00$ & $\mathrm{RN}: 1.71$ & $\mathrm{RN}: 0.52$ \\
\hline & DNP: 4 & DNP: 1 & DNP: 0 & DNP: 0 & DNP: 1.0 & DNP: 1.20 & DNP: 1.40 \\
\hline \multirow{3}{*}{$\begin{array}{l}\text { 3. Teaching nurses genetics/genomics important to keep } \\
\text { nurses as a central partner in patient/family care }\end{array}$} & NE: 17 & NE: 24 & NE: 6 & NE: 1 & NE: 2.00 & NE: 1.83 & NE: 0.80 \\
\hline & RN: 11 & RN: 18 & $\mathrm{RN}: 2$ & $\mathrm{RN}: 0$ & RN: 2.00 & $\mathrm{RN}: 1.71$ & RN: 0.58 \\
\hline & DNP: 3 & DNP: 2 & DNP: 0 & DNP: 0 & DNP: 1.0 & DNP: 1.40 & DNP: 0.49 \\
\hline \multirow{3}{*}{$\begin{array}{l}\text { 4. A family history assessment with genetics/genomics } \\
\text { content (i.e.: pedigree, } 3 \text { generations, age at diagnosis) } \\
\text { have little value for patient care }\end{array}$} & NE: 6 & NE: 6 & NE: 22 & NE: 14 & NE: 3.00 & NE: 2.88 & NE: 0.95 \\
\hline & $\mathrm{RN}: 4$ & $\mathrm{RN}: 0$ & RN: 11 & RN: 7 & $\mathrm{RN}: 3.00$ & RN: 2.97 & RN: 1.15 \\
\hline & DNP: 2 & DNP: 0 & DNP: 2 & DNP: 1 & DNP: 3.0 & DNP: 2.40 & DNP: 1.20 \\
\hline \multirow{3}{*}{$\begin{array}{l}\text { 5. The clinical environment (i.e.: hospital setting; clinical } \\
\text { setting; hospital administration) is motivating me to learn } \\
\text { more about genetics/genomics }\end{array}$} & NE: 9 & NE: 13 & NE: 18 & NE: 5 & NE: 3.00 & NE: 2.68 & NE: 1.17 \\
\hline & RN: 7 & RN: 8 & RN: 11 & RN: 4 & $\mathrm{RN}: 2.00$ & RN: 2.48 & RN: 1.07 \\
\hline & DNP: 2 & DNP: 0 & DNP: 1 & DNP: 2 & DNP: 3.0 & DNP: 2.60 & DNP: 1.36 \\
\hline \multirow{3}{*}{$\begin{array}{l}\text { 6. Taking a genetics/genomics course would help me to } \\
\text { fully integrate this content }\end{array}$} & NE: 22 & NE: 24 & NE: 3 & NE: 0 & NE: 2.00 & NE: 1.68 & NE: 0.76 \\
\hline & RN: 10 & RN: 17 & RN: 3 & RN: 0 & RN: 2.00 & RN: 1.87 & $\mathrm{RN}: 0.83$ \\
\hline & DNP: 3 & DNP: 2 & DNP: 0 & DNP: 0 & DNP: 1.0 & DNP: 1.40 & DNP: 0.49 \\
\hline \multirow{3}{*}{$\begin{array}{l}\text { 7. The importance of nurses to advocate for patients and } \\
\text { society regarding ethical and legal issues about } \\
\text { genetics/genomics }\end{array}$} & NE: 22 & NE: 18 & NE: 2 & NE: 1 & NE: 2.00 & NE: 2.00 & NE: 1.35 \\
\hline & RN: 13 & RN: 18 & $\mathrm{RN}: 1$ & $\mathrm{RN}: 0$ & $\mathrm{RN}: 2.00$ & $\mathrm{RN}: 1.71$ & $\mathrm{RN}: 0.81$ \\
\hline & DNP: 5 & DNP: 0 & DNP: 0 & DNP: 0 & DNP: 1.0 & DNP: 1.00 & DNP: 0.00 \\
\hline
\end{tabular}

Note. *Tally may not equal total of participants due to no answer reported; Nurse Educator (NE; $\mathrm{N}=53)^{*}$; APRN (RN; $\left.\mathrm{N}=31\right)^{*}$; DNP $(\mathrm{N}=5)^{*}$

As shown in Table 4, descriptive comparison of NEs and APRNs represented a minimal to moderate knowledge base of genomic understanding. Understanding what reciprocal translocation in woman's genome would infer (item number 3) only DNP participants (100\%) answered correctly while $16 \%$ NEs and $12.9 \%$ APRNs answered correctly. All participants answered poorly regarding genetic testing (item number 6) with only 9\% NEs, $12.9 \%$ APRNs and $0 \%$ DNP answering correctly. If nurse educators are not adequately prepared to respond to patient inquiries about genetic testing, how can they be expected to educate students. ${ }^{[27,42]}$ While all DNP participants answered correctly to understanding amniocentesis and fetal phenotypic expression, only 38\% NEs and $34.5 \%$ APRNs answered correctly. All participants responded poorly to the interpretation of the genetic inheritance pattern depicted in a patient's pedigree, with only 10 NEs answering correctly, 4 APRNs and 2 DNP participants. This continues to demonstrate that nurse faculty and APRNs need to have an understanding of G-G to realize the variability of genetic conditions and the implications related to clinical practice. Practicing nurses (including nurse academia) lack comprehension and skill in genetic-genomic application in both patient care and education. ${ }^{[15,20,22,32]}$ Majority of participants responded correctly (all over $80 \%$ ) for concepts related to what having one allele of the BRCA1 gene associated with breast cancer means; carrier testing for an Ashkenazi Jewish client and patient concern regarding health insurance and genetic testing (GINA law). The nursing profession is typically well-informed on these concepts. ${ }^{[26,43-45]}$ However, there is scant literature of genomic knowledge specifically on nurse educators who teach in advanced degree practice programs and their students. A replicated study conducted on APRNs ${ }^{[29]}$ compared survey results on prelicensure baccalaureate students ${ }^{[40]}$ with findings revealing perceived genetic knowledge was lacking in both populations, correlating to this study's findings. A comparative analysis of data from 2005 and 2010 exploring nurse educators and APRNs genetic knowledge and comfort levels also demonstrated similar findings to this study's results. ${ }^{[22]}$ A systematic review of literature to establish the scope of nursing practice attaining these core competencies revealed that nurses are not demonstrating the skills to appropriately 
provide care to people with genetic conditions. ${ }^{[39]}$ Faculty are still uncomfortable with this subject content and are inadequately preparing their students. ${ }^{[5,22]}$

Assessment of comfort level, as shown in Table 5, revealed only one aspect that the majority of participants were comfortable in, which was requesting more education about genetic conditions, with 19 NEs, 8 RNs and 2 DNPs very comfortable with this request. Significant low levels of comfort were noted in collecting/drawing/analyzing a 3-generation pedigree with 24 NEs and 20 APRNs responding to not being comfortable while 4 DNPs responded as somewhat comfortable. Not being comfortable in sharing knowledge about G-G in the clinical setting (31 NEs and $20 \mathrm{RNs}$ ); in explaining Mendelian inheritance patterns (25 NEs, 22 RNs and 1 DNP) and in teaching G-G concepts to fellow nurses (33 NEs, 21 RNs and 2 DNPs) demonstrates an overall discomfort with the knowledge and skills needed to integrate these concepts into practice. Unfortunately, nurses deficiency in knowledge, skills and self-confidence in applying genomics to practice and enhancing that confidence is contingent on integrating genetic-genomic education in nursing. ${ }^{[15,46]}$

Finally, as shown in Table 6, all participants agreed it is important for nurses to know and be able to integrate G-G concepts into practice; teach this material to patients and it is the role of the nurse educator to prepare students. The majority (40 NEs, 31 APRNs and 5 DNPs) agreed that nurses need to advocate for patients and society regarding ethical and legal issues about G-G. It is vital for primary care providers to appreciate the ethical, legal and social implications of genetic-genomics. ${ }^{[4]}$ The perception and attitude concerning the importance of genomics integration into education and professional practice is obvious yet there remains an inconsistency of this requisite competency in academic preparation. ${ }^{[48]}$ Majority of participants (except 3 NEs and 3 APRNS) agreed that taking a G-G course would help them to fully integrate this content, correlating to the concept that the nurses' level of knowledge will have a positive effect of confidence and abilities. ${ }^{[32]}$ Being a self-directed learner is essential for these nurses to gain knowledge and confidence with this content. "The effectiveness of nursing curricula in developing genomic competence among students depends upon the knowledge of the faculty and the value they place on the content". ${ }^{[5]}$

\subsection{Educational resources}

A substantial amount of resources are now available for self-directed learning. By exploring the available nursing documents, as seen in Table 1, nurses can gain knowledge and information pertaining to this content. The Genetics Education Program for Nurses (GEPN) at Cincin- nati Children's provides access to continuing education, helping nurses meet genetic and genomic nursing competencies, and instructional resources to help nursing faculty add genetics and genomics content to their curricula (https: //www . cincinnatichildrens . org/educat ion/clinical/nursing/genetics). The International Society of Nurses in Genetics (ISONG) is a global nursing specialty organization dedicated to genomic health care, education, research, and scholarship (http://www . isong. or g). The NIH/National Human Genome Research Institute offers two free sites for article access to further educate nurses on this content (https://www.genome.gov/27552093/; https://www.genome.gov/17515679/).

\subsection{Limitations}

Intrinsically, all research has limitations. The survey was only sent to one graduate program within a university system. As the programs were comprised within one large diverse urban university system results cannot be generalized to other programs or universities. An unfortunate significant constraint was the lack of support in reaching deans, directors and students from the diverse programs within the university system. In addition, it was not feasible to monitor which deans and directors forwarded the survey to their faculty, thus a response rate cannot be provided. The study's results and discussion should be considered within these constraints. Future research should continue to assess nurse educators' and graduate degree nursing professionals' G-G understanding from various programs.

\section{Conclusion}

As the findings of this study suggest, the current actual knowledge base and comfort level of practicing nurses is minimal. Data results of this study will augment the emerging body of evidence that a significant gap continues to exist in the overall knowledge base of nurse educators and practicing nurses enrolled in graduate nursing programs. A prepared nursing workforce is crucial for the translation of genetic-genomics integration into personalized precision healthcare. The exponential expansion of our understanding of genetics-genomics is transforming the healthcare arena. It is the obligation of nurse educators to be well-informed in this newly required competency in order to fully educate students, primarily advanced degree level students, who are expected to practice at a higher efficiency. Promoting the transformation of gen and practice of G-G to advance global health practices and nursing competency is an ever-evolving process that begins with the realization that all educational levels must be involved and informed to integrate this knowledge and confidence into practice to improve patient health outcomes. 


\section{ACKNOWLEDGEMENTS}

The author would like to thank all participants and research assistants. The author received no extramural funding and no commercial financial support in this research.

\section{CONFLicts OF InTEREST Disclosure}

The author declares that there is no conflict of interest.

\section{REFERENCES}

[1] National Institute of Health. National Human Genome Research Institute (NHGRI). 2003. Available from: http://www .genome.gov /10001772

[2] Sharoff L. Holistic nursing in the Genetic/Genomic Era. Journal of Holistic Nursing. 2016; 34(2): 146-153. https ://doi .org/10.1 $177 / 0898010115587401$

[3] Jenkins J, Calzone K, Caskey S, et al. Methods of genomic competency integration into practice. Journal of Nursing Scholarship. 2015; 47(3): 200-210. PMid:25808828 https://doi.org/10.1111/jn u. 12131

[4] Collins C, Stiles A. Predictors of student outcomes on perceived knowledge and competence of genetic family history risk assessment. Journal of Professional Nursing. 2011; 27(2): 101-107. PMid:21420042 https ://doi.org/10.1016/j.profnurs. 201 0.09 .007

[5] Read C, Ward L. Faculty Performance on the Genomic Nursing Concept Inventory. Journal of Nursing Scholarship. 2016; 48(1): 5-13. PMid:26523757 https ://doi.org/10.1111/jnu. 12175

[6] National Coalition for Health Professional Education in Genetics. Core Competencies in Genetics Essential for All HealthCare Professionals. 2007; 3rd Ed. Available from: https://ww w.genome.gov/27554478/ https://www.jax.org/educatio n-and-learning/clinical-and-continuing-education

[7] Sharoff L. Genetics and Genomics Integration into Undergraduate Nursing Education. Journal of Nursing Education and Practice. 2015; 5(4): 13-18. https ://doi.org/10.5430/jnep.v5n4p13

[8] Green E, Guyer M, National Human Genome Research Institute. Charting a course for genomic medicine from base pairs to bedside. Nature. 2011; 470(7333): 204-213. PMid:21307933 https : //doi.org/10.1038/nature09764

[9] Badzek L, Monsen R. Ethical, legal, and social issues in the translation of genomics into healthcare. Journal of Nursing Scholarship. 2016; 45(1): 15-24. PMid:23369261 https://doi.org/10.111 $1 /$ jnu. 12000

[10] American Association of Colleges of Nursing. The Essentials of Baccalaureate Education for Professional Nursing Practice. Washington, DC: American Association of Colleges of Nursing. 2008. Available from: http://www. aacn.nche.edu/education-resources/B accEssentials08.pdf

[11] Consensus Panel on Genetic/Genomic Nursing Competencies. Essentials of Genetic and Genomic Nursing: Competences, Curricula Guidelines, and Outcome Indicators. 2009. Available from: https ://www.genome.gov/pages/careers/healthpro fessionaleducation/geneticscompetency.pdf

[12] Consensus Panel on Genetic/Genomic Nursing \& the American Nurses Association. Essential Genetic and Genomic Competencies for Nurses With Graduate Degrees. 2011. Available from: https://www.genome.gov/pages/health/healthcare providersinfo/grad_gen_comp.pdf

[13] Kirk M, Calzone K, Arimori N, et al. Genetics-genomics competencies and nursing regulation. Journal of Nursing Scholarship. 2011;
43: 107-116. PMid:21605314 https://doi.org/10.1111/j.15 $47-5069.2011 .01388 . x$

[14] American Nurses Association and International Society of Nurses in Genetics. Genetics/Genomics Nursing: Scope and Standards of Practice. Silver Spring, MD: Nursesbooks.org. 2007. Available from: http: //www . nursesbooks . org/Homepage/Hot-off-the-P ress/Genetics-Genomics-Nursing-Scope-and-Standards -2 nd. aspx

[15] Camak D. Increasing importance of genetics in nursing. Nurse Education Today. 2016; 44: 86-91. PMid:27429334 https ://doi.or g/10.1016/j.nedt. 2016.05.018

[16] Williams J, Prow C, Conley Y, et al. Strategies to prepare faculty to integrate genomics into nursing education programs. Journal of Nursing Scholarship. 2011; 43(3): 231-238. https ://doi .org/10 $.1111 / \mathrm{j} .1547-5069.2011 .01401 . \mathrm{x}$

[17] DeSevo M. Genetics and Genomics Resources for Nurses. Journal of Nursing Education. 2010; 49(8): 470-474. PMid:20509591 https : //doi.org/10.3928/01484834-20100524-01

[18] DeSevo M. Competency of nurse educators in genetics/genomics knowledge. Journal of Nursing Education and Practice. 2013; 3(1): 123-129. http://dx.doi.org/10.5430/jnep.v3n1p123

[19] Jenkins J, Calzone K. Are nursing faculty ready to integrate genomic content into curricula. Nurse Educator. 2012; 37(1): 25-29. PMid:22158000 https ://doi.org/10.1097/NNE.0b013e3182 3836 ec

[20] Calzone K, Jenkins J, Culp S, et al. National nursing workforce survey of nursing attitudes, knowledge and practice in genomics. Personalized Medicine. 2013; 10(7): 719-728. PMid:24363765 https://doi.org/10.2217/pme.13.64

[21] Sharoff L. Enhancing Sickle Cell Anemia/Sickle Cell Disease Genetic Understanding through Simulation: A Descriptive Pilot Study. Journal of Nursing Education and Practice. 2015; 5(9): 39-48. https://doi.org/10.5430/jnep.v5n9p39

[22] Maradiegue A, Edwards QT, Seibert D. 5-years later - have faculty integrated medical genetics into nurse practitioner curriculum? International Journal of Nursing Education Scholarship. 2013; 10: 245-254. PMid:24176964 https ://doi.org/10.1515/ijnes-2 012-0007

[23] Daack-Hirsch S, Driessnack M, Perkhounkova Y, et al. A practical first step to integrating genetics into the curriculum. Journal of Nursing Education. 2012; 51(5): 294-298. PMid:22390376 https ://doi.org/10.3928/01484834-20120309-02

[24] Edwards QT, Maradiegue A, Seibert D, et al. Faculty members' perception of medical genetics and it integration into nurse practitioner curricula. Journal of Nursing Education. 2006; 45(3): 124-130. PMid: 16562802

[25] Seibert D. Genomics and nurse practitioner practice. Nurse Practitioner. 2014; 39(10): 18-28. PMid:25208040 https://doi.org/ 10.1097/01. NPR. 0000453641.13662.03

[26] Hughes W, Hopkins M, Maradiegue A. The gene pool: The ethics of genetics in primary care. Annual Review of Nursing Research. 2016; 34: 119-154. PMid:26673380 https ://doi.org/10.1891/0739 $-6686.34 .119$ 
[27] Williams J, Katapodi C, Starkweather A, et al. Advanced nursing practice and research contributions to precision medicine. Nursing Outlook. 2016; 64(2): 117-123. PMid:26712384 https ://doi .or g/10.1016/j.outlook.2015.11.009

[28] Institute of Medicine (IOM). Improving genetics education in graduate and continuing health professional education: Workshop summary. Washington, DC; The National Academies Press; 2015.

[29] Maradiegue A, Edwards QT, Seibert D, et al. Knowledge, perceptions and attitudes of advanced practice nursing students regarding medical genetics. Journal of the American Academy of Nurse Practitioners. 2005; 17: 472-479. PMid:16248880 https: //doi.org/10.1111/j.1745-7599.2005.00076.x

[30] Seibert D, Edwards Q, Maradiegue A. Integrating genetics into advanced practice nursing curriculum: Strategies for success. Public Health Genomics. 2007; 10: 45-51. https://doi.org/10.1159/ 000096278

[31] Coleman B, Calzone KA, Jenkins J, et al. Multi-Ethnic Minority Nurses' Knowledge and Practice of Genetics and Genomics. Journal of Nursing Scholarship. 2014; 46: 235-244. https : //doi .org/10 $.1111 /$ jnu. 12083

[32] Seven M, Akyuz A, Elbuken B, et al. Nurses' knowledge and educational needs regarding genetics. Nurse Education Today. 2014; 35: 444-449. PMid:25475926 https://doi.org/10.1016/j . ne dt.2014.11.008

[33] Sharoff L. Perceived Genetic Knowledge in Pre-Licensure Nursing Students. Journal of Nursing Education and Practice. 2017; 7(2): e-version. https://doi.org/10.5430/jnep.v7n2p10

[34] World Health Organization/Regional Office for Europe. 2017. Available from: http://www.euro.who.int/en/health-top ics/Health-systems/nursing-and-midwifery/data-and -statistics

[35] American Association of Colleges of Nursing. Nursing faculty shortage fact sheet. 2015. Available from: http://www . aacn. nche.ed $\mathrm{u} /$ media-relations/FacultyShortageFS.pdf

[36] National Council of State Boards of Nursing APRN Consensus Model: The Consensus Model for APRN Regulation, Licensure, Accreditation, Certification and Education. 2015. Available from: https://www.ncsbn.org/736.htm

[37] American Association of Nurse Practitioners. NP Fact Sheet. 2016. https://www . aanp.org/all-about-nps/np-fact-sheet
[38] American Association of Colleges of Nursing. DNP Fact Sheet. 2016 Available from: http://www. aacn.nche.edu/media-relatio ns/fact-sheets/dnp

[39] Skirton H, O'Connor A, Humphreys A. Nurses' competence in genetics: A mixed method systematic review. Journal of Advanced Nursing. 2012; 68(11): 2387-2398. https://doi.org/10.1111/ j.1365-2648.2012.06034.x

[40] Dodson C, Lewallen L. Nursing students' perceived knowledge and attitude towards genetics. Nurse Education Today. 2011; 31(4): 333339. PMid:20678829 https://doi.org/10.1016/j.nedt. 201 0.07 .001

[41] Lea D, Skirton H, Read C, Williams J. Implications for educating the next generation of nurses on genetics and genomics in the 21 st century. Journal of Nursing Scholarship. 2011; 43(1): 3-12. PMid:21342419 https://doi.org/10.1111/j.1547-5069.20 10.01373.x

[42] Thompson H, Brooks M. Genetics and genomics in nursing: Evaluating essentials implementation. Nurse Educator Today. 2011; 31(6): 623-627. PMid:21093123 https://doi.org/10.1016/j.nedt .2010 .10 .023

[43] DeLuca J, Zanni K, Bonhomme N, et al. Implications of newborn screening for nurses. Journal of Nursing Scholarship. 2013; 45(1): 25-33. PMid:23368429 https://doi.org/10.1111/jnu.12005

[44] Santos E, Edwards Q, Floria-Santos M, et al. Integration of genomics in cancer care. Journal of Nursing Scholarship. 2013; 45(1): 43-51. PMid:23294839 https://doi .org/10.1111/j.1547-5069.20 $12.01465 . \mathrm{x}$

[45] Jenkins J. Essential genetic and genomic nursing competencies for the oncology nurse. Seminars in Oncology Nursing. 2016; 27(1): 61-71.

[46] Anderson G, Alt-White AC, Schaa KL, et al. Genomics for Nursing Education and Practice: Measuring Competency. Worldviews on Evidence-Based Nursing. 2015; 12: 165-175. https ://doi .org/ 10.1111/wvn. 12096

[47] Whitt KJ, Hughes M, Hopkins EB, et al. The Gene Pool: The Ethics of Genetics in Primary Care. Annual Review of Nursing Research. 2015; 34(1): 119-54. PMid:26673380 https://doi .org/10.189 1/0739-6686.34.119

[48] Calzone K, Jenkins J, Culp S, et al. Introducing a new competency into nursing practice. Journal of Nursing Regulation. 2014; 5(1): 40-47. https ://doi .org/10.1016/S2155-8256 (15) 30098-3 